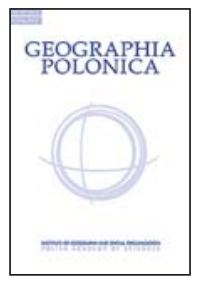

\title{
LONG-TERM LANDSCAPE DYNAMICS IN THE DEPOPULATED CARPATHIAN FOOTHILLS: A WIAR RIVER BASIN CASE STUDY
}

\author{
Andrzej Norbert Affek ${ }^{1}$ (D) Maria Zachwatowicz ${ }^{2}$ (D) Jerzy Solon ${ }^{1}$ \\ ${ }^{1}$ Institute of Geography and Spatial Organization \\ Polish Academy of Sciences \\ Twarda 51/55, 00-818 Warsaw: Poland \\ e-mails: a.affek@igipz.pan.pl (corresponding author)・j.solon@igipz.pan.pl
}

${ }^{2}$ Department of Geoecology, Faculty of Geography and Regional Studies

University of Warsaw

Krakowskie Przedmieście 30, 00-927 Warsaw: Poland

e-mail: m.zachwatowicz@uw.edu.pl

\begin{abstract}
Recently, marginal lands have been attracting attention as areas of high cultural and natural value that are undergoing profound, uncontrolled transformations. These changes are seen as a threat to the cohesion and identity of existing landscapes. However, ongoing processes are often difficult to interpret and evaluate without a long-term historical perspective. Here, we focused on understanding the long-term landscape dynamics in the depopulated and economically marginalized Wiar River basin, where $87 \%$ of inhabitants were displaced after World War II. A detailed, spatially explicit land-cover analysis based on eight series of topographic data (dating from 1780 to 2017), in line with the review of archival sources and literature, allowed us for identification of patterns and drivers of change. We linked the driving forces and the resulting landscape properties to four distinct historical periods (i.e. pre-industrial, industrial, socialist, and free-market). We demonstrated how the landscape of 25 villages, dominated for centuries by open farmland, shifted after WWII into extensively forested, and that not all regions in Europe follow the pattern of increasing rate of land-cover change.
\end{abstract}

\section{Key words}

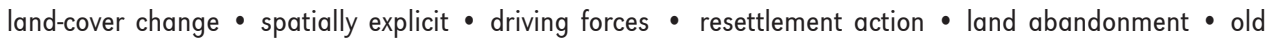
maps - South-east Poland

\section{Introduction}

Socio-political transformations and accompanying technological advances have shaped
European rural landscapes over the last few decades (Van der Sluis, Pedroli, Kristensen, Lavinia Cosor, \& Pavlis, 2014). In accordance with the European Landscape Convention 
(ELC), landscape is seen as a part of European heritage that deserves protection and responsible management (Council of Europe, 2000). To make this possible, the Council of Europe has committed signatories to the Convention to the identification of landscapes on their territories, as well as the analysis of their characteristics and the forces transforming them. A better understanding of not only landscape patterns and their change over time, but above all the driving forces (see Klijn, 2004) and mechanisms responsible for these changes represents one of the key challenges in landscape ecology (Baumann et al., 2011; Bürgi et al., 2017; Bürgi, Hersperger, \& Schneeberger, 2004; Plieninger et al., 2016).

The European Environmental Agency (EEA, 2002) defined driving forces as 'social, demographic and economic developments in societies and the corresponding changes in life styles, overall levels of consumption and production patterns'. These may differ in geographical extent, duration and intensity, and may be direct or indirect (Klijn, 2004). Geist \& Lambin (2002) proposed a division into proximate causes and underlying drivers of change, where the former relate to human activities or immediate actions at the local level (e.g. agricultural expansion, timber extraction), while the latter comprise fundamental social processes (e.g. human population dynamics, agricultural policies) that underpin the proximate causes and either operate at the local level or have an indirect impact from the national or global level (Jepsen et al., 2015; Plieninger et al., 2016). Klijn (2004) notes that the driving forces not only cause landscape change, but can also contribute to the maintenance of balance in a landscape.

It is commonly assumed that changes in the structure and forms of land use since the pre-industrial age are among key factors modifying land cover, biodiversity and climate on Earth. Recent landscape transformations are usually seen as negative processes that pose a threat to the cohesion and identity of historical landscapes, limiting their diversity (Antrop, 2005). Traditional rural landscapes shaped far back in the pre-industrial age are disappearing, and with them a specific land-management culture and spatial order developed down the centuries. Landscape changes exert a strong influence on the stability of ecosystems and their ability to provide services, with this in turn having a direct impact on human well-being (Cabral, Feger, Levrel, Chambolle, \& Basque, 2016; Foley et al., 2005; Metzger et al., 2006; Prishchepov, Müller, Dubinin, Baumann, \& Radeloff, 2013). Progressive habitat fragmentation and habitat loss, deforestation and the increasing share of monocultures are now among the main global directions of change (Foley et al., 2005; Haddad et al., 2015; Pardini, Nichols, \& Püttker, 2018). However, the global trends do not reflect the many - often opposed - processes, that take place on a local scale, such as agricultural marginalisation and land abandonment (see Baldock, Beaufoy, Brouwer, \& Godeschalk, 1996), which in consequence frequently remain overlooked by mainstream policy and science (Plieninger et al., 2016).

Agricultural landscapes in Europe have recently undergone profound change, mainly due to land abandonment for socio-economic reasons (Baldock et al., 1996; Benjamin, Bouchard, \& Domon, 2007; Estel et al., 2015; Kuemmerle et al., 2008; Mottet, Ladet, Coqué, \& Gibon, 2006; Plieninger et al., 2016; Poyatos, Latron, \& Llorens, 2003; Prishchepov et al., 2013). A major driving force leading to land-cover (LC) changes in the early 1990s in Central and Eastern Europe was the collapse of the Soviet Union, and the accompanying transition from state-controlled to market-driven economies (Palang et al., 2006; Prishchepov et al., 2013). Many studies documented the scale and directions of these changes (Feranec, Soukup, Taff, Stych, \& Bičík, 2017; Palang et al., 2006; Peterson \& Aunap, 1998), mainly through wide access to satellite images. However, as recent studies demonstrated, to better understand the current processes and patterns of change, it is crucial to conduct research over longer time horizons to be able to take account of past land-use legacies (Kijowska-Strugała, Bucała-Hrabia, \& Demczuk, 2018; Munteanu 
et al., 2017, 2015). Studies showing landscape dynamics in the spatially explicit way that are based on multi-temporal large-scale cartographic sources are of particular importance here (Bucała-Hrabia, 2017; Eremiášová \& Skokanová, 2009; Haase, Walz, Neubert, \& Rosenberg, 2007; Oláh, Boltižiar, \& Gallay, 2009; Riberio, Burnet, \& Torkar, 2013; Schneeberger, Bürgi, \& Kienast, 2007; Skaloš et al., 2011; Valent, Rončák, Maliariková, \& Behan, 2016).

The goal of this study was to determine and quantify the main patterns and drivers of long-term landscape transformations in the historically depopulated Carpathian Foothills, from the 18th century through to modern times, and to assign landscape properties typical for particular historical periods. In response to a call by the European Landscape Convention, and bearing in mind the representativeness and extrapolation restrictions stated by Bürgi et al. (2004), a specific, landscape-scale study area was chosen for detailed analysis: a basin of the upper Wiar River in the Przemyśl Foothills. The results of empirical analyses were supplemented with findings derived from broad literature review and previous own works.

\section{Study area}

The basin of the upper Wiar River in the eastern part of Polish Carpathians is a rural, hilly region covering $230 \mathrm{~km}^{2}$, located close to the contemporary Polish-Ukrainian border (Fig. 1). The topography ranges between

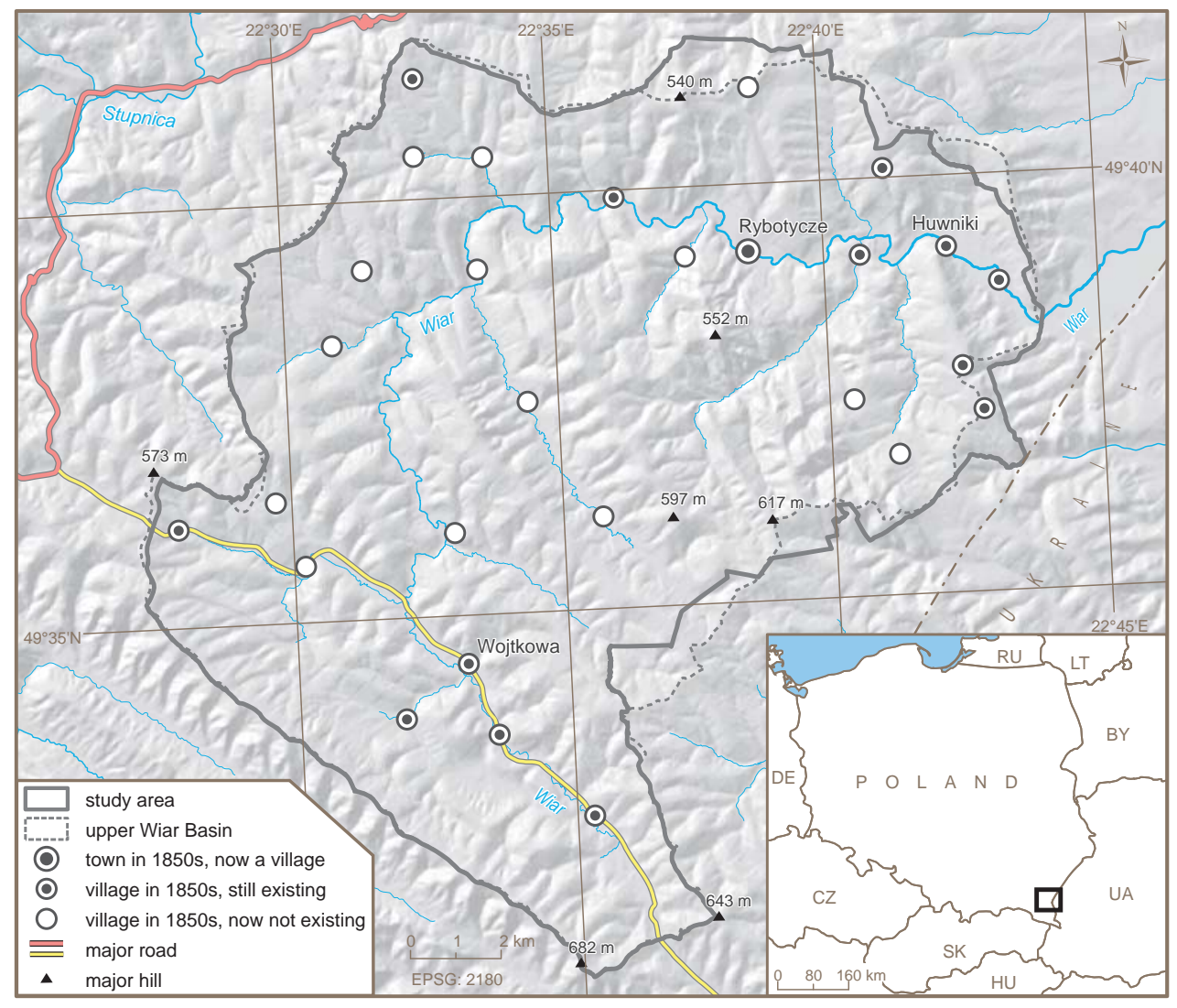

Figure 1. Study area - the upper Wiar River basin in the Polish Carpathian Foothills. The boundaries of the study area were adjusted to the villages' administrative boundaries of 1852 
240 and $670 \mathrm{~m}$ a.s.l. Carpathian flysch (sandstone and shale) is the main bedrock component (Denisiuk \& Stoyko, 2000). Dominant soils include cambisols in the mountains and fluvisols along the rivers. The potential natural vegetation is temperate mixed forest, with beech (Fagus sylvatica) and fir (Abies $a / b a)$ dominating in the upper parts of the basin, and oak (Quercus robur) and hornbeam (Carpinus betulus) in the lower parts (Matuszkiewicz, 2008).

In line with palynological data, current altitudinal zonation of vegetation in the northeastern Carpathians (with oak, hornbeam, lime and maple up to $450 \mathrm{~m}$ a.s.l., beech and fir up to 800 m a.s.l., beech up to 1050 and mountain meadows above $1050 \mathrm{~m}$ ) was shaped by climatic change about 4400 years BP. First evidence of human impact on the landscape (indicators of grazing and local deforestation) was found for the middle Subboreal period (Pelisiak, 2013). From that time through until the 14th century, human interference with the environment assumed differing intensities and directions, but never took the form of a total transformation (Jawor, 2004; Parczewski, Pelisiak, \& Szczepanek, 2016).

Since the Middle Ages, the Wiar River basin and the northern slopes of the Carpathians have been under the control of the Kingdom of Poland. As a result of Poland's partition in 1772 this region was part of the AustroHungarian Empire for the following 146 years, until 1918. Up to World War II, it was a highly-populated Polish-Ukrainian ethnic borderland (with Jewish and German minorities) (Affek, 2016a; Eberhardt, 2011; Maryański, 1963). But, following wartime losses, the Holocaust and especially the forced displacement of Ukrainian-speaking population in the late 1940s (Eberhardt, 2011), overall population density was left at just one-tenth of the level it had been (decreasing from 80 people $/ \mathrm{km}^{2}$ in 1939 to almost 10 in 1950) (Affek, 2016a). Abandoned land underwent nationalisation, with the establishment of state-owned collective farms and forests. Parcels less attractive for agricultural use were afforested with conifers (mainly Scots pine [Pinus sylvestris]), accompanied by spontaneous secondary succession (Augustyn, 2004). Analysis of archival land registers shows that, in the mid-19th century, only $8 \%$ of the area (mainly forests) was state-owned, whereas after World War II - in the socialist era - the corresponding figure was more than 78\% (collectivised farms and almost all forests) (Affek, 2015). After the political transformation of 1989 and the shift from a state-controlled to a market-driven economy, the area of state-owned property decreased to $73 \%$ (in 2008), and is still slowly falling. In the upper Wiar basin, in 1852, there was 1 small town and 24 villages (Affek, 2015). Today, half of these settlements do not exist.

\section{Materials and methods}

To describe the landscape and its transformations, the classic concept of a patch-matrix landscape structure was applied (Forman \& Godron, 1986), with LC patches as primary landscape elements. The study was carried out using the Historical GIS (HGIS) approach (Gregory \& Ell, 2007). Seven series of military topographic maps were used as the source of spatially explicit LC data, their dates ranging from 1780 through to 2000 and scales from 1:25,000 to 1:100,000 (Fig. 2; see Affek, 2011 for map description). The smallest scale map (the Tactical Map of Poland of 1936) is known for its precision and accuracy (Krassowski, 1974) and does not differ greatly in terrain representation from older topographic maps on larger scales. The eighth most recent $L C$ layer was derived from the national Topographic Database (BDOT10k) (vector format, accuracy equivalent to a map scale of 1:10,000). The Database, dated 2013, was updated with Google Earth orthophoto of July 2017. All the maps were scanned and georeferenced in a GIS environment, in line with the procedure proposed by Affek (2013). The Root Mean Square Error (RMSE) of adjustment (affine transformation) for maps based on geodetic networks varied between $4 \mathrm{~m}$ and $30 \mathrm{~m}$. The oldest map series (1780) was georeferenced using spline (rubbersheeting) 


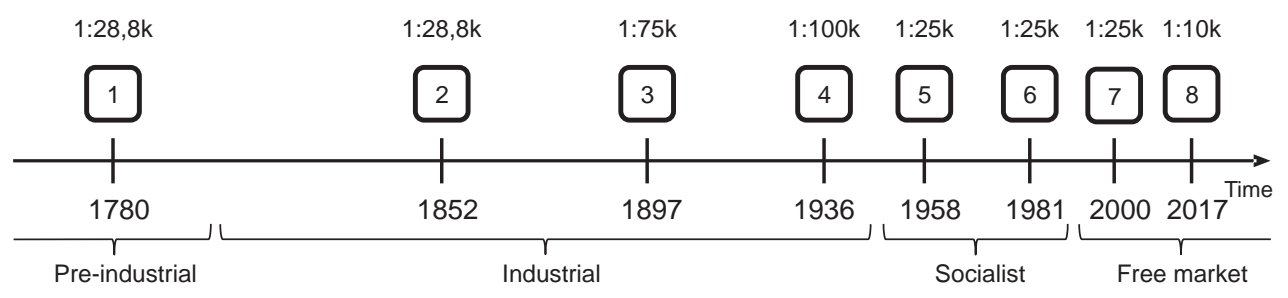

Figure 2. Date of content acquisition and scale for each spatial source data located on the timeline. Spatial data: 1, 2, 3 - First, Second and Third Military Survey of the Habsburg Empire; 4, 5, 6, 7 - Military Topographic Maps; 8 - Topographic Database (BDOT10k) updated with Google Earth orthophoto

transformation. The scanned maps were brought to a common projected coordinate system - PL 1992 (EPSG: 2180) and vectorised. To ensure comparability of the LC vector layers, it was necessary to set a Minimum Mapping Unit (MMU) common to all layers (Rocchini, 2005). This was achieved by eliminating all polygons smaller than the smallest polygon on the coarsest of the LC data sets $\left(\mathrm{MMU}=2000 \mathrm{~m}^{2}\right)$. Polygons were eliminated by merging them with neighbouring ones of largest area.

Rasterisation was the next step in standardising the LC layers and reducing match errors. Raster cell size should, on the one hand, be greater than the highest RMSE value obtained during georeferencing $(30 \mathrm{~m})$ (Geri, Rocchini, \& Chiarucci, 2010). On the other hand, to additionally ensure retention of the already-truncated LC information (by setting a common MMU), the size of the raster cell should not exceed MMU size $\left(\sqrt{2000 \mathrm{~m}^{2}} \approx 45 \mathrm{~m}\right)$. Looking at the extreme values already defined, we decided to set the raster cell to $1600 \mathrm{~m}^{2}$, which corresponds to a resolution of $40 \mathrm{~m}$. The rasterisation procedure and vector data aggregation were performed in line with the majority rule applied commonly in aggregating discrete spatial data, in ecology and remote sensing (Wu, 2004).

Due to large differences between map legends (numbers and meanings of items, etc.) only three LC classes common for all 8 time slices were distinguished and further analysed: forest, farmland and settlements. Transition matrices were used to analyse gross
LC changes in each interval separately (Solon, 2009). These show (by reference to percentages of the total area) what proportion of land assignable to a given LC class transformed to another over a given time interval. Transitions representing no change (e.g. forest $\rightarrow$ forest) were also included. In order to minimise the risk of overlooked LC transitions, the time periods of the cross sections were not only chosen so that the intervals had the shortest possible duration, but also to capture the key regime shifts and their effects (e.g. shortly before and after the world wars, and before and after major political transformations) (Fig. 2). The time range of 237 years allowed us also to capture LC composition in the pre-industrial age, before mid-19th century agrarian changes took place. In addition, with Polish territory it was also possible to catch a glimpse of a landscape typical of the era before the partitioning of Poland and the reign of the Habsburg Monarchy (since 1772).

Annual rates of forest-cover change were calculated in line with the formula given by Puyravaud (2003), which has been accepted by the Food and Agriculture Organisation as a standard method in global forest assessments (Kozak, 2010).

Cause-and-effect analysis and interpretation of results were based not only on our own findings derived from cartographic analysis but also on the thorough review of scientific literature and descriptive archival sources, such as censuses, and land and tax registers (see Appendices 1-6 to Affek 2016a). The memories of individuals were also utilised, 
with some of these available in written form (e.g. http://rybotycze.blogspot.com/; https:// www.apokryfruski.org/), while others came from four qualitative interviews conducted with senior members of the local community in 2010-2013. Human-induced driving forces and the resulting landscape properties were assigned to four recognisable eras falling within the time horizon of the research, i.e. the pre-industrial, industrial, socialist, and free-market (Fig. 2).

\section{Results - drivers and patterns of change linked to landscape properties in historical periods}

\section{The pre-industrial age}

The first abrupt man-made landscape change in the study area took place in the Late Middle Ages and was the effect of a massive transformation in land ownership, i.e. the granting of Crown lands to the gentry (Tab. 1). This triggered planned colonisation of extensive areas (most villages in the Wiar basin were founded under Wallachian law in the 15th century; K. Wolski, 1956) and a large population influx, which in turn resulted in the development of farmland at the expense of woodland (Jawor, 2004). With the increase in population came rising demand for arable land and pasture (Williams, 2003). From then on, farmland became a dominant LC class with traditional agricultural terraces, hollow ways, border mounds, ditches etc. (Affek, 2016b). Although wood was used only for local needs, due to limited transport possibilities, the then popular potash production and clearing for agriculture resulted in ongoing reduction in forest cover (Żabko-Potopowicz, 1956). The feudal system and related large legal and financial inequalities resulted in different LC patterns on land owned by the landlords (forests and large fields) as opposed to the peasantry (almost no forests, a mosaic of small plots) (Affek, 2016a; Żabko-Potopowicz, 1956).

At the end of the pre-industrial age, the landscape began to be influenced by new driving forces stemming from the inclusion of the voivodeships of Małopolskie and Lwowskie within the Austrian Empire, forming the new Province of Galicia (Kozak, 2010). New Austrian regulations on the use and ownership of land, which came into force at the end of the 18th century, aimed to limit depletion of both private and state forests, but brought no significant effect (Żabko-Potopowicz, 1956).

Between 1780 and 1852, the upper Wiar basin witnessed the greatest deforestation within the analysed time horizon (11\% of the total area, 25\% of the forest cover as of 1780; farmland reached $57 \%$ of the area, Fig. 3). Forest cover in the mid-19th century reached the lowest value in the history of the study area - 38\%. Spatial analysis demonstrates that forests were mainly cleared in ravines and on slopes less suited for cultivation, but located close to settlements. The agro-forest boundary, understood as the upper field margin on mountain slopes, was also then elevated in the main mountain ranges, by $100 \mathrm{~m}$ on average. The ratio of forests to settlement areas and farmland was of approx. 8:1:11. We believe that this ratio can be considered typical of the traditional pre-industrial rural landscape, whose framework was shaped far back in the 16th century.

\section{The industrial age}

With the abolition of serfdom in 1848 , peasants were deprived of the opportunity to benefit from manor forests, which in turn led to the reforestation of the least productive land held by peasants and the community. Afforested land was located on ridges and in V-shaped valleys far from settlement, previously used for grazing. In parallel, new forest law limiting the freedom to deforest was introduced (Broda, 1985).

Spatial analysis of LC transitions indicated, that in the 19th century small net changes of LC classes were accompanied by significant gross changes, demonstrating the synchronous occurrence of the processes of expansion and retreat of each LC class 

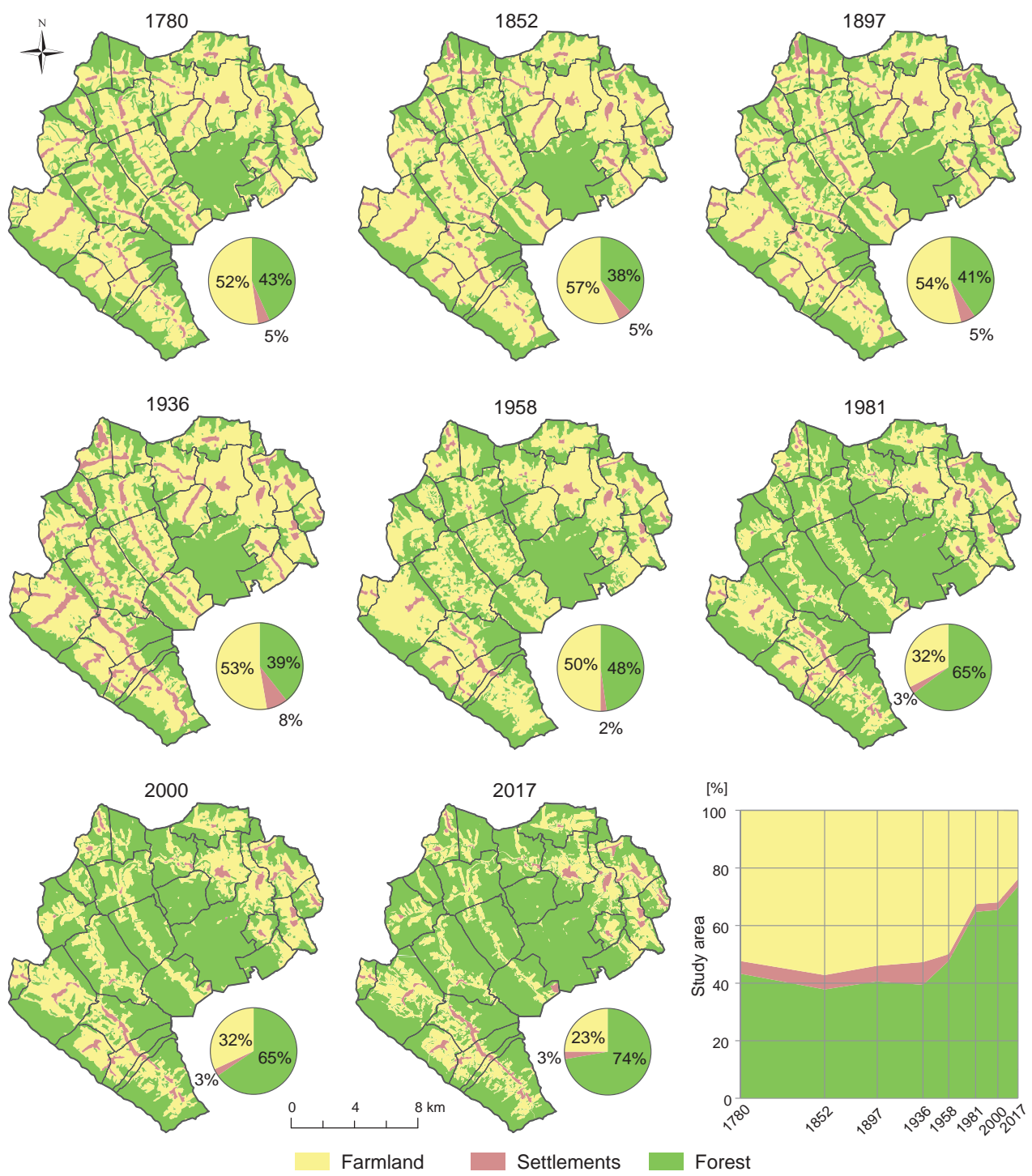

Figure 3. Land cover of the upper Wiar River basin in eight time slices

in different parts of the study area (e.g. new compact forest patches observed on the ridge lines of the study area, significant fluctuations in forest-farmland boundary, etc.) (Fig. 3, 4).

From the mid-19th century onwards, the Carpathians experienced a demographic explosion resulting from the gradual taming of epidemic diseases and other elementary disasters (Augustyn, 2004; Zamorski, 1991).
It is considered the most important underlying driving force of landscape change at that time (Tab. 1). At the turn of the century, the rate of growth in the population in the study area reached 1.64\% per year (Affek, 2016a). As a result of widespread overpopulation and 'land hunger' in the Galician countryside, almost every square metre of peasant land was cultivated (Leslie, Polonsky, Ciechanowski, \& Pelczynski, 1983). 
Table 1. Major driving forces, related land use changes and the resulting landscape properties in the four historical periods

\begin{tabular}{|c|c|c|c|}
\hline Age & $\begin{array}{l}\text { Underlying causes/ } \\
\text { driving forces }\end{array}$ & $\begin{array}{l}\text { Proximate causes / } \\
\text { changes in land use }\end{array}$ & Landscape properties \\
\hline 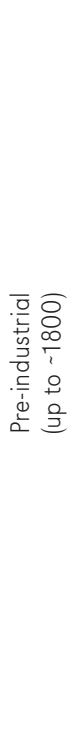 & $\begin{array}{l}\text { Granting of Crown-held land } \\
\text { to the gentry } \\
\text { Influxes of people, } \\
\text { population growth } \\
\text { Local production and consump- } \\
\text { tion } \\
\text { Feudalism }\end{array}$ & $\begin{array}{l}\text { Clearing of woodland, founding } \\
\text { of settlements } \\
\text { Gradual development of settle- } \\
\text { ments and agro-pastoral system, } \\
\text { extensive farming } \\
\text { Felling of trees for timber, fire- } \\
\text { wood, charcoal and potash, } \\
\text { Creation of mill races to gener- } \\
\text { ate mechanical energy } \\
\text { Different land use by landlords } \\
\text { (forests, large fields), and peas- } \\
\text { antry (no forests, mosaic of small } \\
\text { plots) }\end{array}$ & $\begin{array}{l}\text { - Evolutionary development } \\
\text { from natural to cultural } \\
\text { landscape } \\
\text { - Main transitions: forest } \rightarrow \\
\text { fields, pastures, settlements } \\
\text { - Formation of landscape } \\
\text { boundaries in line with owner- } \\
\text { ship boundaries } \\
\text { - Main landscape functions: } \\
\text { grazing and agriculture } \\
\text { - Mosaic of small patches } \\
\text { on peasantry land, large } \\
\text { patches on gentry-owned and } \\
\text { Crown land } \\
\text { - Clearly separated enclaves } \\
\text { of settlement areas } \\
\text { - Numerous landscape transfor- } \\
\text { mations (including topography) } \\
\text { for defence purposes } \\
\text { - Remodelling of water network } \\
\text { for power generation } \\
\text { - Road network mainly along } \\
\text { ridgelines }\end{array}$ \\
\hline 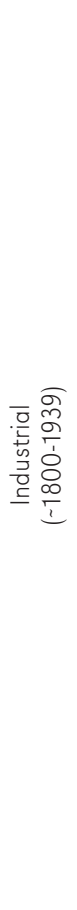 & $\begin{array}{l}\text { Austrian colonisation } \\
\text { Industrialisation } \\
1848 \text { abolition of serfdom } \\
\text { Agricultural revolution } \\
\text { Development of railways } \\
\text { Development of trade }\end{array}$ & $\begin{array}{l}\text { Densification of the settlement } \\
\text { network } \\
\text { Glass factories and oil mines, ex- } \\
\text { ploitation of surrounding forests, } \\
\text { settlements for workers } \\
\text { Parcelling of large estates, affor- } \\
\text { estation of peasantry land due } \\
\text { to abolition of forest easements } \\
\text { Afforestation of fields least } \\
\text { suited to cultivation } \\
\text { Clear-cuts along railways, } \\
\text { steam-powered timber mills } \\
\text { New transport network (new des- } \\
\text { tinations, paved roads leading } \\
\text { through valleys (unlike previous } \\
\text { road network along ridges, } \\
\text { to avoid mud)) } \\
\text { Intensive exploitation of peas- } \\
\text { antry land } \\
\text { Further parcelling of land estates } \\
\text { Clear-cuts - timber needed } \\
\text { to build military structures, e.g. } \\
\text { the Przemyśl Fortress }\end{array}$ & $\begin{array}{l}\text { - Evolutionary development } \\
\text { of cultural landscape } \\
\text { - Main transitions: forest, fields } \\
\rightarrow \text { settlements; pastures } \rightarrow \\
\text { fields } \\
\text { - Settlement expansion: isolated } \\
\text { settlements eventually forming } \\
\text { chains } \\
\text { - Road network mainly in valleys } \\
\text { - Open farmland as evident } \\
\text { landscape matrix } \\
\text { - The sharpest landscape } \\
\text { boundaries and largest num- } \\
\text { ber of patches in history } \\
\text { - Large number of linear } \\
\text { features in landscape: field } \\
\text { margins, hedgerows, field } \\
\text { roads } \\
\text { - Further systematic fragmenta- } \\
\text { tion of landscape mosaic } \\
\text { - New landscape function: } \\
\text { industrial production }\end{array}$ \\
\hline
\end{tabular}




\begin{tabular}{|c|c|c|c|}
\hline Age & $\begin{array}{l}\text { Underlying causes/ } \\
\text { driving forces }\end{array}$ & $\begin{array}{l}\text { Proximate causes / } \\
\text { changes in land use }\end{array}$ & Landscape properties \\
\hline 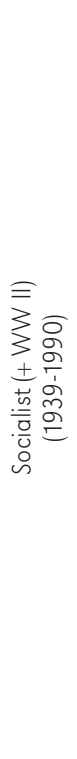 & $\begin{array}{l}\text { WW II (Holocaust, war losses) } \\
\text { Displacement of ethnic minori- } \\
\text { ties } \\
1944 \text { land reform (expropriation } \\
\text { of landlords, nationalisation } \\
\text { of abandoned land) } \\
\text { Foundation of a government } \\
\text { hunting lodge }\end{array}$ & $\begin{array}{l}\text { Massive afforestation and } \\
\text { secondary succession on aban- } \\
\text { doned farmland, collapse of set- } \\
\text { tlements } \\
\text { Radical 'reclamation' of mosaic } \\
\text { of fertile fields with hedgerows } \\
\text { into open-spaced, state-owned } \\
\text { monocultures } \\
\text { Further displacement of inhabit- } \\
\text { ants and levelling of remains } \\
\text { of villages, creation of forest } \\
\text { openings and clearings for hunt- } \\
\text { ing, large herbivores that are } \\
\text { over-abundant and disrupt forest } \\
\text { natural growth (overgrazing) } \rightarrow \\
\text { creation of open forests }\end{array}$ & $\begin{array}{l}\text { - Revolutionary development } \\
\text { - } \text { Radicultural landscape } \\
\text { activity - reduction of human } \\
\text { pressure on natural systems } \\
\text { - Main transitions: pastures, } \\
\text { fields, settlement areas } \rightarrow \\
\text { forest; settlement areas } \rightarrow \\
\text { farmland } \\
\text { - Regression of settlement } \\
\text { network } \\
\text { - Decline in landscape diversity } \\
\text { - Landscape matrix conversion } \\
\text { from farmland to forest } \\
\text { - Rapid increase in numbers } \\
\text { of large wild herbivores, } \\
\text { in parallel with sharp decrease } \\
\text { in number of livestock } \\
\text { - Decrease in number and } \\
\text { length of linear features } \\
\text { - Fuzzy boundaries between } \\
\text { LC patches, broad ecotone } \\
\text { zones; increase in sizes of field } \\
\text { and forest patches }\end{array}$ \\
\hline 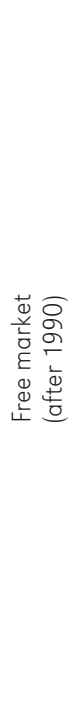 & $\begin{array}{l}\text { International market competition } \\
\text { - economic calculation } \\
\text { Partial redistribution (re-privati- } \\
\text { sation) of land (excluding forests) } \\
\text { Tourism and agro-tourism } \\
\text { EU Accession: } \\
\text { Common Agricultural Policy } \\
\text { (CAP), Agri-environmental plan- } \\
\text { ning, EU Nature Conservation } \\
\text { Policy } \\
\\
\text { Specialisation in agricultural } \\
\text { production } \\
\text { Polarisation of space (extensifica- } \\
\text { tion and intensification) }\end{array}$ & $\begin{array}{l}\text { Collapse of collective farming } \rightarrow \\
\text { agricultural abandonment } \\
\text { Intensive Forest Management } \\
\text { Second homes, recreational } \\
\text { areas } \\
\text { Further afforestation of unculti- } \\
\text { vated land } \\
\text { Private extensive ecological } \\
\text { farming (beekeeping, mainte- } \\
\text { nance of NATURA } 2000 \text { habi- } \\
\text { tats), demand of land for nature } \\
\text { conservation (nature and herit- } \\
\text { age conservation activities). } \\
\text { Extensive use of land (margin- } \\
\text { alisation) - afforestation, scrub, } \\
\text { meadows (grass) harvested for } \\
\text { silage }\end{array}$ & $\begin{array}{l}\text { - Revolutionary development } \\
\text { of cultural landscape } \\
\text { - Shift in human activity: } \\
\text { increased pressure on wood- } \\
\text { land, decreased on agricul- } \\
\text { tural areas } \\
\text { - Basic transitions: fields } \rightarrow \\
\text { mown meadows, forest; } \\
\text { pastures } \rightarrow \text { mown meadows, } \\
\text { forest } \\
\text { - Further decline in landscape } \\
\text { diversity - increased domi- } \\
\text { nance of forests } \\
\text { - Sharp further decline in live- } \\
\text { stock } \\
\text { - Shift of settlement function } \\
\text { from residential to recrea- } \\
\text { tional } \\
\text { - Disappearance of landscape } \\
\text { linear features } \\
\text { - Smooth edges between } \\
\text { LC patches, extremely broad } \\
\text { ecotone zones; }\end{array}$ \\
\hline
\end{tabular}

Source: Own elaboration based on the results of the current study, former works (Affek, 2011, 2015, 2016a, 2016b; Affek, Zachwatowicz, Sosnowska, Gerlée, \& Kiszka, 2017), as well as on other sources, including: Augustyn, 2004; Klijn, 2004; Kozak, 2010; Wolski, 2007. 

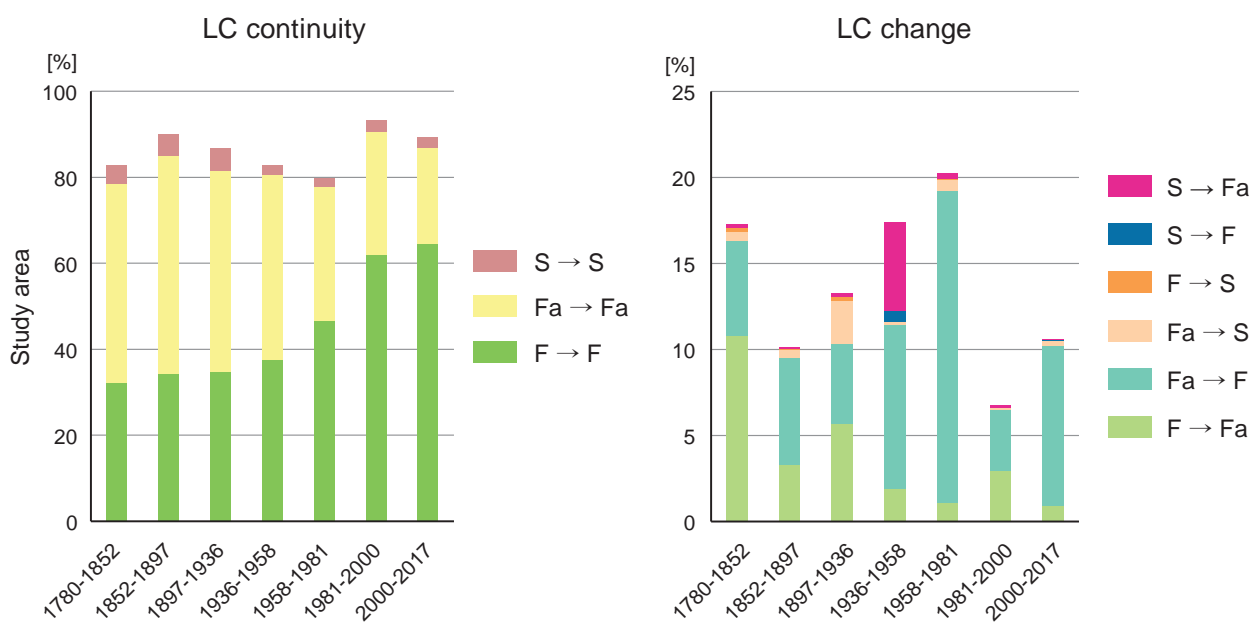

Figure 4. Graphic representation of LC transitions divided into two groups: transitions of continuity and transitions of change ( $\mathrm{F}$ - Forest; Fa - Farmland; $\mathrm{S}$ - Settlements)

In addition, the development of railroads and oil wells brought the Industrial Revolution to the Eastern Polish Carpathians. This provoked intensive exploitation of forests and raw materials, no longer for local needs only, but mainly for export (Williams, 2003). Oil wells, steam-powered sawmills and wood processing plants were founded, together with adjacent workers' settlements (Augustyn, 2004). The development of means of transport and growing needs in this regard combined with access to road-building materials and technology contributed to a major rearrangement of the road network. The existing unpaved roads running along mountain ridges were replaced by a network of paved roads leading through the valleys.

While land was used very intensively at this stage, the LC composition in the upper Wiar basin was not altered more considerably. Settlement areas expanded slowly, mainly in the form of new hamlets. Farmland (arable land and pastures) still accounted for the majority of the land cover, and this trend continued into the inter-war period.

Population and material losses due to World War I only slowed population growth briefly (Affek, 2016a). Augustyn (2004) pointed to marked local variation in social and economic development, even between neighbouring villages. The shape of the landscape was increasingly being affected by driving forces related directly to qualities characterising landlords, mainly as regards wealth and entrepreneurship.

The first half of the 20th century brought the greatest expansion of the settlement network in the analysed time horizon. More than 620 ha of built-up area emerged, mostly at the expense of agricultural land.

The largest transition in this period was deforestation for agriculture $5.7 \%$ of the study area, Fig. 3). This primarily concerned commons and peasantry land (as of 1852) that had been just afforested. The land reform of 1920 triggered further parcellingoff of manor land, with this in turn propelling forward fragmentation of the landscape. High population density, with most people making their living from agriculture, combined with far-reaching land fragmentation, contributed to landscape boundaries of maximum sharpness and a larger number of patches than at any time in the history of the study area. Linear features in the landscape (field margins, hedgerows and field roads) also reached their highest numbers at that time (Affek, 2016a). 


\section{World War II}

With the outbreak of World War II and the new order introduced by its outcome, new driving forces came into play (Williams, 2003). In place of the economic and individual factors, purely political processes began to shape the landscape of the Eastern Polish Carpathians (Tab. 1). Major demographic transformations had taken place during the War. The Nazi and Soviet invasions decimating Poles and Ukrainians, while local multicultural communities were deprived, first of their Jews (in the Holocaust) and then Germans (by expulsion) (Eberhardt, 2011). However, it was only the forced resettlement of the Ukrainian-speaking population after the War, arising from border shifts and implementation of the ideology of mononational states, that led to total landscape transformation (Affek, 2011; Eberhardt, 2011; Maryański, 1963).

At that time, as a result of the burning or demolition of farms, settlement areas shrank in the study area by more than $70 \%$. Eight out of 24 villages ceased to exist entirely, while in the next several villages only a few out of hundreds of pre-war homes survived (the settlement area decreased from 8\% of the study area in 1936 to 2,3\% in 1958, Fig. 3). All the wooden manor houses in the upper Wiar basin were destroyed, whereas churches generally survived both the War and population displacements, including a large number of wooden Greek-Catholic churches that stood alone for many years in deserted villages. This was the only period over the last 237 years during which the settlement area failed to grow.

\section{The socialist era}

Population decline of $87 \%$ in the years 1939 1950 (Affek, 2016a) triggered a series of processes in the landscape of the study area, resulting from the reduction in human pressure on the natural environment. This coincided with the strategic objective implemented at the central-planning level to increase forest cover in the mountains and to lower the agro-forest boundary (Kozak, 2010). Hence, large areas of forest emerged in this period, with almost none cleared (Fig. 3, 4). This new afforestation appeared in the neighbourhood of ancient forests, on less-accessible fields and pastures in the abandoned villages, consisting mainly of pine monocultures, sometimes with larch and spruce, from planting and natural secondary succession. The average annual forest-cover increase between cross-sections from 1936 to 1981 was $1.14 \%$ (from $39 \%$ to $65 \%$ ). In the central depopulated part of the basin (8300 ha), this increase reached a level as high as $1.63 \%$ per annum. In fact though, forest growth only began in 1947, after the end of the expulsions. The largest increase in forest cover was observed between 1958 and 1981 (nearly $20 \%$ increase in forest cover), which is from 11 to 34 years after resettlement. Considering the exploitative forest management practises of the occupying forces, actual forest cover after World War II was even lower than in 1936. It is highly probable, therefore, that in the first 30 years after the War (1947-1977) the depopulated central part of the basin featured an annual forest-cover increase exceeding $3 \%$, generating an overall forest-cover increase of approx. 150\%.

In parallel with a substantial change in landscape composition, the overall landscape pattern also underwent changes. Over extensive agricultural areas, the only narrow strips remaining under cultivation were in the valleys. Landscape diversity thus fell considerably in comparison with the pre-war period (Affek, 2016a). Low land-use intensity resulted in fuzzy boundaries between LC patches and in broad ecotone zones.

Demographic changes, accompanied by changes in the political system resulted in a new land ownership structure (Affek, 2015). The aftermath of the expulsions saw land expropriation, re-parcelling and collectivisation, largely unlike in the Western Polish Carpathians where continuity of settlement was maintained (Kozak, 2010). In place of demolished homes, various buildings associated 
with collective farming (State Farms and agricultural cooperatives) came into existence. Abandoned churches became the property of State Farms or the State Forests Holding and were used as warehouses that decayed and fell apart steadily, not surviving through to modern times. The mosaic of fertile fields with hedgerows was turned either into large open-space, fields or state-owned forest monocultures.

During this period, a recolonization unique in the 20th century Europe took place (Maryański, 1963). Individual settlers founded new villages on bare ground in areas that had been deserted for at least a decade. For instance, in 1959 in the former village of Jureczkowa, after 12 years without any occupants, 49 farming families were given newly-delimited parcels of land that bore no relation to the pre-war settlement network (Maryański, 1963).

An important new driving force on the regional scale was the decision made by the Council of Ministers Office in the 1960s, to establish in the central, desolate part of the study area, an exclusive hunting lodge for members of the ruling elite and distinguished foreign guests (Białkowski, 2002). This resulted in further displacement of inhabitants and levelling of the remains of villages. Arable land assigned to this resort (thousands of hectares) was maintained mainly in the form of meadows and pastures. The surrounding old-growth forest was turned into park-like open forest, since large herbivores maintained for hunting purposes were over-abundant, and cleared the undergrowth.

Changes in employment structure taking place were soon reflected in LC changes (Fig. 3). The number of people earning their living from agriculture decreased, as young people migrated to the industrial centres. Local population data for the upper Wiar basin reflect these demographic shifts (Affek, 2016a). Between 1960 and 1988, the resident population density decreased by $17 \%$. This contributed to further agricultural marginalisation.

\section{The free-market era}

Poland's 1989 transformation of its political and economic systems (Dudek, 2014) ushered in a new chapter in the history of the study area. Market laws and the forces of competition led to the collapse of poorly managed collective farms, the result being abandonment of agricultural land, and secondary succession of forest. Furthermore, traditional, individual agricultural production in mountainous areas could not withstand the competition. In response to the weakening of agriculture in marginal areas, a National Programme for Expanding of Forest Cover (Krajowy Program Zwiększania Lesistości - KPZL) was introduced in 1995, to some extent continuing the post-War policy in this regard (Kozak, 2010).

The accession of Poland to the European Union and implementation of the Common Agricultural Policy within the framework of Cohesion Policy triggered a new social understanding of the value of rural areas (Rdzanek, 2014). The EU's agri-environmental schemes and subsidies for farmers operating in adverse conditions (including mountainous areas) have affected land cover in the basin (Fig. 3). Hectares of fallow land have been cleared of scrub and converted into mown meadows (Affek, 2016a). The areas unsuitable for agriculture have been (re)afforested. Notable changes have also characterised areas of settlement. New residential and holiday homes have emerged, often beyond the existing strip of buildings, while other remote hamlets have been abandoned. However, the magnitude of changes has been limited by a new wave of migration in search of work, to cities, as well as abroad (Tab. 1).

The comparison of maps from 2000 and 2017 shows a further phase of marked increase in the area of forest (by $0.71 \%$ per year). The largest new patches emerged as a result of 1990s afforestation of hard-toreach farmland, located at higher altitudes and owned by the bankrupt State Farms. In turn, the farmland area reached the lowest noted value of $23 \%$ (Fig. 3). The new forests 


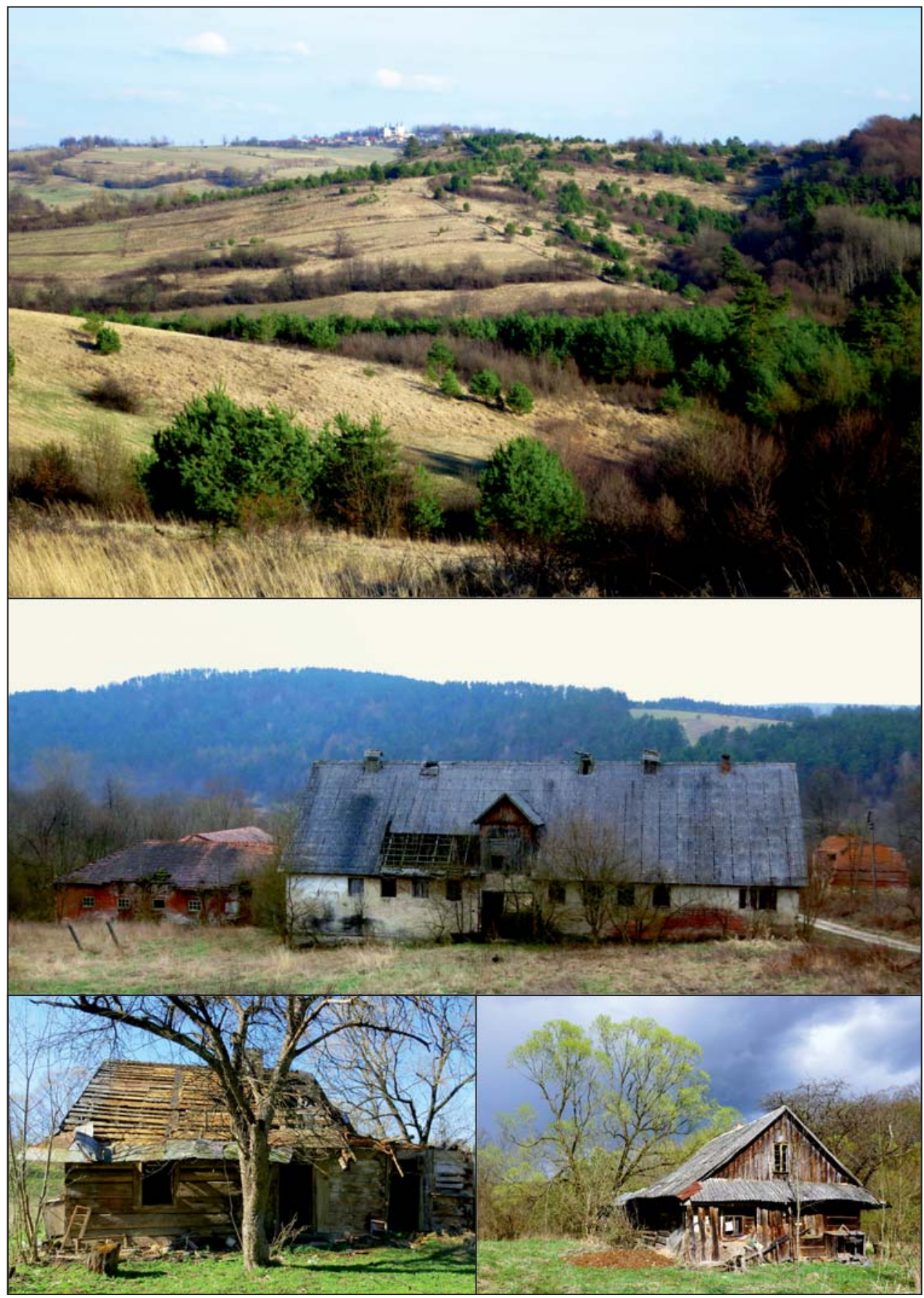

Figure 5. Land abandonment in the Wiar River basin after the socio-political transformation of the 1990s. Top - forest succession on former arable land, middle - abandoned socialist collective farm, bottom - abandoned individual farms. 
were mainly spruce monocultures not corresponding with the potential natural vegetation. The most recent assessment of the study area - carried out in 2017 - revealed extensive areas of scrub and young forest plantation that did not come under the definition of forest cover in the preceding period (Fig. 5). This indicates that forests continue to dominate the landscape by way of a process that will most likely progress further, due to both secondary succession and intentional afforestation. By reaching its peak level of $74 \%$ as of 2017, forest cover was almost doubled what it had been 70 years earlier (Fig. 3).

\section{Discussion and conclusions}

Our results contribute to the understanding of how much regime shifts may impact landscape dynamics. Two major landscape transformations were identified in the study area, both resulting in a significant forest expansion, driven by settlement discontinuity after WWII, and land abandonment in the 2000s. Post-WWII policy of forced resettlements of national minorities led to economic marginalization. The Wiar basin experienced the most significant changes in mid-20th century, and now in the post-socialist period is in the second, less intensive phase of the ongoing marginalisation. The massive afforestation and natural secondary succession on abandoned, nationalised land was maintained through the socialist policy regime, only to be driven further, though much less exhaustively, by economic transitions from a centrallyplaned to a market-driven economy taking place from the 1990s through to today, even following Poland's accession to the EU. In consequence, the landscape dominated up to the WWII by open farmland shifted into extensively forested (from 39\% in 1936 to more than $70 \%$ in 2017). Still, in the areas where the settlements have been partly preserved, the forest expansion seems to be much less evident.

The landscape dynamics outlined above contradicts the observations of Antrop (2005) that the post-World War II European landscapes experience the gradually accelerating
LC change. Certainly, transformations are much more pronounced after World War II than in the pre-War period, though with no gradual acceleration of changes following the War's end. Similarly, reports from different European countries by other authors (e.g. Bürgi et al., 2017; Schneeberger et al., 2007) are of high temporal variability in rates of longterm landscape transformation, with rates of long-term land cover change not always increasing over the study period, to the extent that the most-recent period has often even been associated with comparatively low rates of change. We therefore showed that also in Poland there are regions that do not follow the pattern of accelerated LC changes, which complements the concept of Antrop (2005) regarding traditional landscapes.

The main political and socio-economic drivers revealed in our study are distinctive, not only for the Wiar River basin, but also for other rural regions of Central and Eastern Europe, which in the industrial/imperial age formed parts of the Austrian, Ottoman and Russian Empires, only to come within the communist orbit after World War II, before being transformed into market economies in the 1990s, and experiencing EU accession and subsequent membership in the 2000s. Post-War collectivisation of agriculture with resultant destruction of the field mosaic affected most of the former-Soviet Baltic Republics in the north down to the former Yugoslavia in the south (Giovarelli \& Bledsoe, 2001). The cultural continuity and centuries-old landscape identity were lost in almost all cases. But collective farming usually did not survive the political and economic transition of the 1990s. Some of the farms were abolished because of the restitution of land to former owners who by then had no further plans to cultivate it, while other farms collapsed in the face of unprofitability of production (Giovarelli \& Bledsoe, 2001). This led to another widespread process of the abandonment of agricultural land, with many new owners turning their arable land into grassland or forest (on the basis of agri-environmental schemes), or just keeping it unmaintained for speculative purposes. 
While the regions meeting all these criteria can be found in Estonia, Latvia, Lithuania, Poland, the Czech Republic, Slovakia, Hungary, Romania, Bulgaria, Slovenia and Croatia (Giovarelli \& Bledsoe, 2001), the trends detailed above can be thought to apply in particular to borderlands and areas formerly inhabited by national minorities, in which politically-driven displacement led to permanent depopulation and economic marginalisation. Such areas exist in south-eastern Poland (the site of expulsions of Ukrainians: e.g. Affek, 2011, 2016a; Augustyn, 2004; Janicki, 2004; Palang et al., 2006; J. Wolski, 2007; Woś, 2005), the Eastern Polish Sudetes (expulsions of Germans, e.g. Latocha (2012), the Czech Sudetenland (expulsions of Germans, e.g. Bičík \& Štěpánek, 1994), the Slovenian Carniola (expulsions of Italians and Germans, e.g. Hladnik, 2005; Kobler, Cunder, \& Pirnat, 2005), and the Latvian Uplands (deportations of residents to the Soviet Union, e.g. Nikodemus et al., 2005).

Referring to the European Landscape Convention, our results highlighted the importance of landscape assessments, and learning from the past for better understanding of long-term landscape changes, and in turn for better informed landscape policies. Certainly, calibrating land-system policies providing for past trends is challenging not only in terms of unexpected political or economic shifts, but also other regime shifts, where sudden events occur (e.g. natural disasters) or critical thresholds in underlying drivers are crossed (e.g. as regards climate conditions or commodity prices) (Müller et al., 2014). The actions aiming at landscape protection, management and planning should be therefore preceded by the comprehensive understanding of driving forces and mechanisms transforming the certain area, and preferably supported also with comparative studies from other areas characterised by similar development histories.

\section{Acknowledgements}

Earlier stages of this research were presented in the doctoral thesis of A. Affek, which was published in Polish by his mother institution (Affek, 2016a).

\section{Editors' note:}

Unless otherwise stated, the sources of tables and figures are the authors', on the basis of their own research.

\section{References}

Affek, A. (2011). Landscape continuity versus landscape transformation: a case study in the Wiar River catchment, Polish Carpatians (1780-2000). Problemy Ekologii Krajobrazu, 30, 147-155.

Affek, A. (2013). Georeferencing of historical maps using GIS, as exemplified by the Austrian Military Surveys of Galicia. Geographia Polonica, 86(4), 375-390. https://doi.org/10.7163/GPol.2013.30

Affek, A. (2015). Spatially explicit changes in land ownership through 3 socio-political systems: a case study from southeast Poland. Geographia Polonica, 88(3), 519-530. https://doi.org/10.7163/GPol.0032

Affek, A. (2016a). Dynamika krajobrazu: uwarunkowania i prawidłowości na przykładzie dorzecza Wiaru w Karpatach (XVIII-XXI wiek). Prace Geograficzne, 251, Warszawa: Instytut Geografii i Przestrzennego Zagospodarowania PAN. [in Polish, with English summary]

Affek, A. (2016b). Past Carpathian landscape recorded in the microtopography. Geographia Polonica, 89(3), 415-424. https://doi.org/10.7163/GPol.0062

Affek, A., Zachwatowicz, M., Sosnowska, A., Gerlée, A., Kiszka, K. (2017). Impacts of modern mechanised skidding on the natural and cultural heritage of the Polish Carpathian Mountains. Forest Ecology and Management, 405(December), 391-403. https://doi.org/10.1016/j.foreco.2017.09.047 
Antrop, M. (2005). Why landscapes of the past are important for the future. Landscape and Urban Planning, 70(1-2), 21-34. https://doi.org/10.1016/j.landurbplan.2003.10.002

Augustyn, M. (2004). Anthropogenic changes in the environmental parameters of Bieszczady Mountains. Biosphere Conservation, 6(1), 43-53.

Baldock, D., Beaufoy, G., Brouwer, F., Godeschalk, F. (1996). Farming at the margins: Abandonment or redeployment of agricultural land in Europe. London: Institute for European and Environmental Policy and Agricultural Economics Research Institute.

Baumann, M., Kuemmerle, T., Elbakidze, M., Ozdogan, M., Radeloff, V.C., Keuler, N.S., ... Hostert, P. (2011). Patterns and drivers of post-socialist farmland abandonment in Western Ukraine. Land Use Policy, 28(3), 552-562. https://doi.org/10.1016/j.landusepol.2010.11.003

Benjamin, K., Bouchard, A., Domon, G. (2007). Abandoned farmlands as components of rural landscapes: An analysis of perceptions and representations. Landscape and Urban Planning, 83(4), 228-244. https://doi.org/10.1016/j.landurbplan.2007.04.009

Białkowski, W. (2002). Arłamów bez kurtyny: tajne łamane przez poufne. Arłamów: Ośrodek Wypoczynkowy "Arłamów." [in Polish]

Bičík, I., Štěpánek, V. (1994). Post-war changes of the land-use structure in Bohemia and Moravia: Case study Sudetenland. GeoJournal, 32(3), 253-259.

Broda, J. (1985). Proces wylesienia na ziemiach polskich od czasów najdawniejszych. Czasopismo Geograficzne, 56, 151-173. [in Polish]

Bucała-Hrabia, A. (2017). Long-term impact of socio-economic changes on agricultural land use in the Polish Carpathians. Land Use Policy, 64, 391-404. https://doi.org/10.1016/j.landusepol.2017.03.013

Bürgi, M., Bieling, C., von Hackwitz, K., Kizos, T., Lieskovský, J., Martín, M.G., ... Printsmann, A. (2017). Processes and driving forces in changing cultural landscapes across Europe. Landscape Ecology, 32(11), 2097-2112. https://doi.org/10.1007/s10980-017-0513-z

Bürgi, M., Hersperger, A.M., Schneeberger, N. (2004). Driving forces of landscape change - current and new directions. Landscape Ecology, 19(8), 857-868. https://doi.org/10.1007/s10980-004-0245-8

Cabral, P., Feger, C., Levrel, H., Chambolle, M., Basque, D. (2016). Assessing the impact of land-cover changes on ecosystem services: A first step toward integrative planning in Bordeaux, France. Ecosystem Services, 22, 318-327. https://doi.org/10.1016/j.ecoser.2016.08.005

Council of Europe. European Landscape Convention, ETS No. 17 Report and Convention Florence $\S$ (2000). https://doi.org/http://conventions.coe.int/Treaty/en/Treaties/Html/176.htm

Denisiuk, S., Stoyko, S.M. (2000). The East Carpathian biosphere reserve (Poland, Slovakia, Ukraine). In A. Breymeyer, P. Dabrowski (Eds.), Biosphere Reserves on Borders (pp. 79-93). Warsaw: UNESCO.

Dudek, A. (2014). The consequence of the system transformation of 1989 in Poland. Remembrance and Solidarity Studies, (3), 11-39. Retrieved from http://www.enrs.eu/studies_files/3/\#/11

Eberhardt, P. (2011). Political migrations on Polish territories (1939-1950). Warszawa: Instytut Geografii i Przestrzenngo Zagospodarowania PAN.

EEA. (2002). Environment signals 2002: benchmarking the Millennium. Environmental Assessment Report no. 9. Copenhagen. Retrieved from http://www.eea.europa.eu/publications/environmental_assessment_report_2002_9

Eremiášová, R., Skokanová, H. (2009). Land use changes (recorded in old maps) and delimitation of the most stable areas from the perspective of land use in the Kašperské Hory Region. Journal of Landscape Ecology, 2(1), 20-34. https://doi.org/10.2478/v10285-012-0012-5

Estel, S., Kuemmerle, T., Alcántara, C., Levers, C., Prishchepov, A., Hostert, P. (2015). Mapping farmland abandonment and recultivation across Europe using MODIS NDVI time series. Remote Sensing of Environment, 163, 312-325. https://doi.org/10.1016/j.rse.2015.03.028 
Feranec, J., Soukup, T., Taff, G.N., Stych, P., Bičík, I. (2017). Overview of changes in land use and land cover in Eastern Europe. In Land-cover and land-use changes in Eastern Europe after the collapse of the Soviet Union in 1991 (pp. 13-33). https://doi.org/10.1007/978-3-319-42638-9_2

Foley, J.A., Defries, R., Asner, G.P., Barford, C., Bonan, G., Carpenter, S.R., ... Snyder, P.K. (2005). Global consequences of land use. Science, 309(5734), 570-574. https://doi.org/10.1126/science.1111772

Forman, R.T.T., Godron, M. (1986). Landscape ecology. New York: Wiley.

Geist, H.J., Lambin, E.F. (2002). Proximate causes and underlying driving forces of tropical deforestation. BioScience, 52(2), 143. https://doi.org/10.1641/0006-3568(2002)052[0143:PCAUDF]2.0.CO;2

Geri, F., Rocchini, D., Chiarucci, A. (2010). Landscape metrics and topographical determinants of largescale forest dynamics in a Mediterranean landscape. Landscape and Urban Planning, 95(1-2), 46-53. https://doi.org/10.1016/j.landurbplan.2009.12.001

Giovarelli, R., Bledsoe, D. (2001). Land reform in Eastern Europe - Western CIS, Transcaucuses, Balkans, and $E U$ accession countries. Seattle, Washington.

Gregory, I.N., Ell, P.S. (2007). Historical GIS: techniques, methodologies and scholarship. Cambridge: Cambridge University Press.

Haase, D., Walz, U., Neubert, M., Rosenberg, M. (2007). Changes to Central European landscapes Analysing historical maps to approach current environmental issues, examples from Saxony, Central Germany. Land Use Policy, 24(1), 248-263. https://doi.org/10.1016/j.landusepol.2005.09.003

Haddad, N.M., Brudvig, L.A., Clobert, J., Davies, K.F., Gonzalez, A., Holt, R.D., ... Townshend, J.R. (2015). Habitat fragmentation and its lasting impact on Earth's ecosystems. Science Advances, 1(2), e1500052. https://doi.org/10.1126/sciadv.1500052

Hladnik, D. (2005). Spatial structure of disturbed landscapes in Slovenia. Ecological Engineering, 24, 17-27. https://doi.org/10.1016/j.ecoleng.2004.12.004

Janicki, R. (2004). Specific features of the landscape succession processes in Przemyskie Foothills. In K. Kirchner, J. Wojtanowicz (Eds.), Cultural landscapes. Brno: Regiograph.

Jawor, G. (2004). Osady prawa wołoskiego i ich mieszkańcy na Rusi Czerwonej w późnym średniowieczu (2nd ed.). Lublin: Wydawnictwo Uniwersytetu Marii Curie-Skłodowskiej. [in Polish]

Jepsen, M.R., Kuemmerle, T., Müller, D., Erb, K., Verburg, P.H., Haberl, H., ... Reenberg, A. (2015). Transitions in European land-management regimes between 1800 and 2010. Land Use Policy, 49, 53-64. https://doi.org/10.1016/j.landusepol.2015.07.003

Kijowska-Strugała, M., Bucała-Hrabia, A., Demczuk, P. (2018). Long-term impact of land use changes on soil erosion in an agricultural catchment (in the Western Polish Carpathians). Land Degradation and Development, 29(6), 1871-1884. https://doi.org/10.1002/Idr.2936

Klijn, J.A. (2004). Driving forces behind landscape transformation in Europe, from a conceptual approach to policy options. In R. H. G. Jongman (Ed.), The new dimensions of the European landscape (pp. 201218). Dordrecht: Springer.

Kobler, A., Cunder, T., Pirnat, J. (2005). Modelling spontaneous afforestation in Postojna area, Slovenia. Journal for Nature Conservation, 13(2-3), 127-135. https://doi.org/10.1016/j.jnc.2005.01.003

Kozak, J. (2010). Forest cover changes and their drivers in the Polish Carpathian Mountains since 1800. In H. Nagendra, J. Southworth (Eds.), Reforesting landscapes: linking pattern and process (pp. 253273). https://doi.org/10.1007/978-1-4020-9656-3

Krassowski, B. (1974). Polska kartografia wojskowa w latach 1918-1945. Warszawa: Wojskowy Instytut Historyczny, Wydawnictwo MON. [in Polish]

Kuemmerle, T., Hostert, P., Radeloff, V.C., van der Linden, S., Perzanowski, K., Kruhlov, I. (2008). Crossborder comparison of post-socialist farmland abandonment in the Carpathians. Ecosystems, 11, 614628. https://doi.org/10.1007/s10021-008-9146-z

Latocha, A. (2012). Changes in the rural landscape of the Polish Sudety Mountains in the post-war period. Geographia Polonica, 85(4), 13-21. https://doi.org/10.7163/GPol.2012.4.21 
Leslie, R.F., Polonsky, A., Ciechanowski, J.M., Pelczynski, Z.A. (1983). The history of Poland since 1863. (R.F. Leslie, Ed.). Cambridge: Cambridge University Press.

Maryański, A. (1963). Współczesne migracje ludności w południowej części pogranicza polsko-radzieckiego i ich wpływ na rozmieszczenie sił wytwórczych tego obszaru. Kraków: Wyższa Szkoła Pedagogiczna w Krakowie.

Matuszkiewicz, J.M. (2008). Potencjalna roślinność naturalna Polski [Potential natural vegetation of Poland]. Retrieved July 14, 2017, from https://www.igipz.pan.pl/tl_files/igipz/ZGiK/opracowania/roslinnosc_potencjalna/prn_opracowanie.pdf

Metzger, M.J., Rounsevell, M.D.A., Acosta-Michlik, L., Leemans, R., Schroter, D., Schröter, D. (2006). The vulnerability of ecosystem services to land use change. Agriculture, Ecosystems and Environment, 114(1), 69-85. https://doi.org/10.1016/j.agee.2005.11.025

Mottet, A., Ladet, S., Coqué, N., Gibon, A. (2006). Agricultural land-use change and its drivers in mountain landscapes: A case study in the Pyrenees. Agriculture, Ecosystems \& Environment, 114(2-4), 296-310. https://doi.org/10.1016/j.agee.2005.11.017

Munteanu, C., Kuemmerle, T., Boltiziar, M., Lieskovský, J., Mojses, M., Kaim, D., ... Radeloff, V.C. (2017). Nineteenth-century land-use legacies affect contemporary land abandonment in the Carpathians. Regional Environmental Change. https://doi.org/10.1007/s10113-016-1097-x

Munteanu, C., Kuemmerle, T., Keuler, N.S., Müller, D., Balázs, P., Dobosz, M., ... Radeloff, V.C. (2015). Legacies of 19th century land use shape contemporary forest cover. Global Environmental Change, 34, 83-94. https://doi.org/10.1016/j.gloenvcha.2015.06.015

Müller, D., Sun, Z., Vongvisouk, T., Pflugmacher, D., Xu, J., Mertz, O. (2014). Regime shifts limit the predictability of land-system change. Global Environmental Change, 28(1), 75-83. https://doi.org/10.1016/j.gloenvcha.2014.06.003

Nikodemus, O., Bell, S., Grine, I., Liepinšs, I. (2005). The impact of economic, social and political factors on the landscape structure of the Vidzeme Uplands in Latvia. Landscape and Urban Planning, 70(1-2), 57-67. https://doi.org/10.1016/j.landurbplan.2003.10.005

Oláh, B., Boltižiar, M., Gallay, I. (2009). Transformation of the Slovak cultural landscape since the 18th Cent. and its recent trends. Journal of Landscape Ecology, 2(2), 41-55. https://doi.org/10.2478/v10285-012-0018-z

Palang, H., Printsmann, A., Gyuró, É.K., Urbanc, M., Skowronek, E., Woloszyn, W. (2006). The forgotten rural landscapes of Central and Eastern Europe. Landscape Ecology, 21(3), 347-357. https://doi.org/10.1007/s10980-004-4313-x

Parczewski, M., Pelisiak, A., Szczepanek, K. (2016). Bieszczady Zachodnie w pradziejach i średniowieczu w świetle danych archeologicznych oraz palinologicznych. In Jacek Wolski (Ed.), Bojkowszczyzna Zachodnia - Wczoraj, dziś i jutro. Tom 1 (pp. 315-359). Warszawa: Instytut Geografii i Przestrzennego Zagospodarowania PAN.

Pardini, R., Nichols, E., Püttker, T. (2018). Biodiversity response to habitat loss and rragmentation. In Encyclopedia of the Anthropocene (pp. 229-239). https://doi.org/10.1016/B978-0-12-809665-9.09824-4

Pelisiak, A. (2013). Man and mountains. Settlement and economy of Neolithic communities in the Eastern part of the Polish Carpathians. Studien Zur Achaologie in Ostmitteleuropa / Studia Nad Pradziejami Europy Środkowej, 11, 225-244.

Peterson, U., Aunap, R. (1998). Changes in agricultural land use in Estonia in the 1990s detected with multitemporal Landsat MSS imagery. Landscape and Urban Planning, 41(3-4), 193-201. https://doi.org/10.1016/S0169-2046(98)00058-9

Plieninger, T., Draux, H., Fagerholm, N., Bieling, C., Bürgi, M., Kizos, T., ... Verburg, P.H. (2016). The driving forces of landscape change in Europe: A systematic review of the evidence. Land Use Policy, 57, 204214. https://doi.org/10.1016/j.landusepol.2016.04.040 
Poyatos, R., Latron, J., Llorens, P. (2003). Land use and land cover change after agricultural abandonment. Mountain Research and Development, 23(4), 362-368. https://doi.org/10.1659/0276-4741(2003)023[0362:LUALCC]2.0.CO;2

Prishchepov, A.V., Müller, D., Dubinin, M., Baumann, M., Radeloff, V.C. (2013). Determinants of agricultural land abandonment in post-Soviet European Russia. Land Use Policy, 30(1), 873-884. https://doi.org/10.1016/j.landusepol.2012.06.011

Puyravaud, J.-P. (2003). Standardizing the calculation of the annual rate of deforestation. Forest Ecology and Management, 177(1-3), 593-596. https://doi.org/http://dx.doi.org/10.1016/S0378-1127(02)00335-3

Rdzanek, D. (2014). The influence of the Common Agricultural Policy and UE funds on rural development after the accession of Poland to the European Union. Polish Political Science Yearbook, 43. Retrieved from http://www.marszalek.com.pl/yearbook/docs/43/ppsy2014017.pdf

Riberio, D., Burnet, J.E., Torkar, G. (2013). Four windows on borderlands: dimensions of place defined by land cover change data from historical maps. Acta Geographica Slovenica, 53(2), 317-342.

Rocchini, D. (2005). Resolution problems in calculating landscape metrics. Journal of Spatial Science, 50(2), 25-35. https://doi.org/10.1080/14498596.2005.9635047

Schneeberger, N., Bürgi, M., Kienast, P.D.F. (2007). Rates of landscape change at the northern fringe of the Swiss Alps: Historical and recent tendencies. Landscape and Urban Planning, 80(1-2), 127-136. https://doi.org/10.1016/j.landurbplan.2006.06.006

Skaloš, J., Weber, M., Lipský, Z., Trpáková, I., Šantrůčková, M., Uhlířová, L., Kukla, P. (2011). Using old military survey maps and orthophotograph maps to analyse long-term land cover changes - Case study (Czech Republic). Applied Geography, 31(2), 426-438. https://doi.org/10.1016/j.apgeog.2010.10.004

Solon, J. (2009). Spatial context of urbanization: Landscape pattern and changes between 1950 and 1990 in the Warsaw metropolitan area, Poland. Landscape and Urban Planning, 93(3-4), 250-261. https://doi.org/10.1016/j.landurbplan.2009.07.012

Valent, P., Rončák, P., Maliariková, M., Behan, ̌̌. (2016). Utilization of historical maps in the land use change Impact Studies: A case study from Myjava River Basin. Slovak Journal of Civil Engineering, 24(4), 15-26. https://doi.org/10.1515/sjce-2016-0018

Van der Sluis, T., Pedroli, B., Kristensen, S.B.P., Lavinia Cosor, G., Pavlis, E. (2014). Changing land use intensity in Europe - Recent processes in selected case studies. Land Use Policy. https://doi.org/10.1016/j.landusepol.2014.12.005

Williams, M. (2003). Deforesting the earth: From prehistory to global crisis. Chicago, London: The University of Chicago Press.

Wolski, J. (2007). Przekształcenia krajobrazu wiejskiego Bieszczadów Wysokich w ciagu ostatnich 150 lat. Prace Geograficzne, 214, Warszawa: Institut Geografii i Przestrzennego Zagospodarowania PAN.

Wolski, K. (1956). Osadnictwo dorzecza górnego Wiaru w XV wieku. Annales Universitas Marie Curie Skłodowska, Sectio B, XI, (1), 1-47. [in Polish]

Woś, B. (2005). Zmiany pokrycia terenu w wybranych gminach Beskidów w drugiej połowie XX w. na podstawie analizy zdjęć lotniczych. Teledetekcja Środowiska, 35, 1-114. [in Polish]

Wu, J. (2004). Effects of changing scale on landscape pattern analysis: Scaling relations. Landscape Ecology, 19(2), 125-138. https://doi.org/10.1023/B:LAND.0000021711.40074.ae

Zamorski, K. (1991). Transformacja demograficzna w Galicji na tle przemian ludnościowych innych obszarów Europy Środkowej w drugiej połowie XIX i na początku XX w. Kraków: Nakładem Uniwersytetu Jagiellońskiego.

Żabko-Potopowicz, A. (1956). Lasy i leśnictwo na ziemiach Polski w pierwszej połowie XIX wieku. Sylwan, 100(7), 58-87. 